\title{
Notes on Australian Meliaceae
}

\author{
D.J. Mabberley
}

\begin{abstract}
Mabberley, D.J., (Rijksuniversiteit Leiden, Netherlands and Royal Botanic Gardens Sydney, Mrs Macquaries Road, Sydney NSW 2000, Australia) 1998. Notes on Australian Meliaceae. Telopea 8(1): 47-48. Dysoxylum amooroides Miq. is lectotypified and Turraea decandra Blanco neotypified; Owenia capitisyorkii Domin is reduced to O. vernicosa; Synoum muelleri is recognised as a subspecies of S. glandulosum - subsp. paniculosum (F. Muell.) Mabb., stat. nov.
\end{abstract}

\section{Introduction}

The following notes were intended as an Appendix to the Flora of Australia account of Meliaceae, which was prepared in 1989, but has been unavoidably held up in publication. As the findings are needed for other publications, they are presented here.

\section{Dysoxylum Blume}

Dysoxylum gaudichaudianum (A. Juss.) Miq.

Turraea decandra Blanco, Fl. Filip.: 347 (1837).

Type (designated here): Philippines: Luzon, Manila, E.D. Merrill Sp. Blancoanae 218; neo: L; isoneo: A, BM, BO, G, K, NSW, P, PNH lost.

D. decandrum (Blanco) Merr., Philip. Gov. Lab. Publ. 27: 30 (1905).

D. amooroides Miq., Ann. Mus. Bot. Lugd.-Bat. 4: 16 (1868).

Type (selected here):[Indonesia: south-west Irian Jaya,] A. Zippelius s.n.; lecto: U; isolecto: L.

D. gaudichaudianum has been widely known in Australia as D. decandrum (Blanco) Merr. or D. amooroides Miq., neither of which names has been precisely typified. As Blanco's specimens are lost, Merrill collected a new series and his 'illustrative' specimen collected near the type site of T. decandra is an appropriate choice for a neotype, even though the PNH specimen itself is lost, as it is so well-represented as duplicates in other herbaria. Of the syntype sheets quoted by Miquel in his description of $D$. amooroides, the Zippelius sheet is represented in Miquel's own herbarium and duplicated at Leiden, making it a suitable lectotype.

\section{Owenia F. Muell.}

Owenia vernicosa F. Muell., Fragm. 3: 15 (1862).

O. capitis-yorkii Domin, Biblioth. Bot. 22 (894): 854 (1927).

Type: Queensland: Cape York, W. Hann, Cape York Expedition 115 holo (?): PR/PRC, n.v.[see below]; iso (holo?): K; syn. nov.

Domin described $O$. capitis-yorkii from a single leaf and drupe without its epicarp. He compared it with O. acidula F. Muell. and O. vernicosa F. Muell., from which it appeared 
to differ in leaflet characters. With more collections of O. vernicosa, the scrappy type falls within the range exhibited by that species. According to the curators, there is no extant material at PR or PRC and the fact that Domin mentions specifically the scraps which match the Kew sheet suggests that the Hann specimen there (Hann specimens not known to be preserved elsewhere) is the basis for the description.

Synoum A. Juss.

Synoum glandulosum (Sm.) A. Juss.

subsp. paniculosum (F. Muell.) Mabb., stat. nov.

S. glandulosum var. paniculosum F. Muell., Fragm. 5: 145 (1866, as 'Synoon glandulosum var. paniculosa')

Type: Queensland: Rockingham Bay, 1865, J. Dallachy s.n.; holo: MEL; iso: BM, BRI, L. S. muelleri C.DC., Monog. Phan. 1: 593, t. 7 fig. 10 (1878)

Type: Queensland: Rockingham Bay, 'Ferd. Muell. in h. Berol.'; holo: B, lost; iso?: (J. Dallachy s.n.): BM, BRI, L, MEL.

The northernmost populations of $S$. glandulosum have very long thyrses and pentamerous flowers; Mueller gave them varietal status and, probably based on a duplicate of the same gathering, C. de Candolle recognised them at species level as S. muelleri. Occasionally pentamerous flowers and rather intermediate inflorescence sizes are found in trees further south so that it would seem more appropriate to recognize the northern populations as a geographical subspecies rather than a separate species. 